\title{
Peranan Penerapan Standar Kesehatan dan Keselamatan Kerja Pada UD. Berkat
}

Yamolala Zega

Sekolah Tinggi Ilmu Ekonomi Pembangunan

zyamolala@gmail.com

\begin{abstract}
Abstrak Penelitian ini menggunakan metode pendekatan kualitatif yaitu prosedur penelitian yang menghasilkan data deskriptif berupa kata-kata tertulis atau lisan dari orang-orang dan perilaku yang dapat diamati. Penelitian ini bertujuan untuk mengetahui apakah penerapan Standar Kesehatan Dan Keselamatan Kerja Pada UD. Berkat sudah memenuhi standar. Dari hasil penelitian diketahui hal-hal sebagai berikut : Pertama, Kesehatan kerja yang diterapkan oleh UD. Berkat menunjukkan bahwa Pemberian jaminan kesehatan bagi seluruh karyawan, penerapan jam kerja yang sesuai dan pemberian beban yang sesuai dengan kemampuan karyawan. Frekuensi nilai kesehatan kerja di UD. Berkat menunjukkan bahwa rata-rata jawaban responden sebesar 3,537 yang berarti bahwa tingkat kesehatan di UD. Berkat tergolong tinggi. Kedua, Keselamatan kerja yang diterapkan oleh UD. Berkat menunjukkan bahwa perusahaan memberikan alat pelindung diri bagi karyawan yang bekerja. Ini dilakukan untuk mengurangi resiko kecelakaan kerja. Frekuensi nilai keselamatan kerja di UD. Berkat menunjukkan bahwa rata-rata jawaban responden sebesar 3,715 yang berarti bahwa tingkat kesehatan di UD. Berkat tergolong tinggi
\end{abstract}

Keywords Penerapan, Kesehatan dan Keselamatan Kerja

\section{PENDAhuluaN}

Keselamatan dan kesehatan kerja merupakan suatu upaya untuk menjamin keutuhan dan kesempurnaan baik jasmani maupun rohani bagi seorang pekerja. Dengan keselamatan dan kesehatan kerja maka para pihak diharapkan dapat melakukan pekerjaan dengan aman dan nyaman. Pekerjaan dikatakan aman jika apapun yang dilakukan oleh pekerja tersebut, resiko yang mungkin muncul dapat dihindari. Pekerjaan dikatakan nyaman jika para pekerja yang bersangkutan dapat melakukan pekerjaan dengan merasa nyaman dan betah, sehingga tidak mudah capek.

Menurut Tulus (1992:159), Salah satu faktor yang mempengaruhi produktivitas kerja adalah kesehatan kerja, perusahaan perlu memelihara kesehatan para karyawan, kesehatan ini menyangkut kesehatan fisik ataupun mental. Kesehatan para karyawan yang buruk akan mengakibatkan kecenderungan tingkat absensi yang tinggi dan produksi yang rendah. Adanya program kesehatan yang baik akan menguntungkan para karyawan secara material, karena mereka akan lebih jarang absen bekerja dengan lingkungan yang menyenangkan, sehingga secara keseluruhan akan mampu bekerja lebih lama berarti lebih 
produktif. Program kesehatan kerja dapat dilakukan dengan penciptaan lingkungan kerja yang sehat. Hal ini menjaga kesehatan dari gangguan-gangguan penglihatan, pendengaran, kelelahan dan lain-lain. Penciptaan lingkungan kerja yang sehat secara tidak langsung akan mempertahankan atau bahkan meningkatkan produktivitas. Program kesehatan kerja tidak terlepas dari program keselamatan kerja, karena dua program tersebut tercakup dalam pemeliharaan terhadap karyawan. Keselamatan kerja merupakan keselamatan yang bertalian dengan mesin, pesawat, alat kerja, bahan dan proses pengolahannya, landasan tempat kerja dan lingkungannya serta cara-cara melakukan pekerjaan. Keselamatan kerja bersasaran segala tempat kerja , baik didarat, didalam tanah, dipermukaan air, didalam air, maupun diudara. "Keselamatan kerja merupakan sarana untuk pencegahan kecelakaan, cacat, dan kematian sebagai akibat kecelakaan kerja" (Suma'mur, 1993:1).

Penyebab kecelakaan kerja ada empat faktor diantaranya: faktor nasib dari para karyawan, faktor lingkungan fisik pada karyawan, seperti mesin, gedung, ruangan, peralatan. Faktor kelalaian manusia dan faktor ketidakserasian kombinasi faktor-faktor produksi yang dikelola dalam perusahaan (Soeprihanto, 1996:47). Keselamatan kerja erat bersangkutan dengan peningkatan produksi dan produktivitas. Keselamatan kerja dapat membantu peningkatan produksi dan produktivitas atas dasar : Dengan tingkat keselamatan kerja yang tinggi, kecelakaan-kecelakaan yang menjadi sebab sakit, cacat dan kematian dapat ditekan sekecil-kecilnya. Tingkat keselamatan yang tinggi sejalan dengan pemeliharaan dan penggunaan peralatan kerja dan mesin yang produktif dan efisien dan bertalian dengan tingkat produksi dan produktivitas yang tinggi (Suma'mur, 1993:4).

UD. Berkat merupakan suatu usaha yang bergerak dalam bidang pembuatan batu bata dan menyewakan alat-lat berat, UD. Berkat menganggap penting variabel program keselamatan kerja dan kesehatan kerja, hal tersebut dibuktikan dengan adanya penggunaan alat-alat perlindungan diri seperti sarung tangan dan masker ditempat kerja, ada pengaturan udara yang cukup, dan ada petunjuk dan peringatan ditempat kerja.

Menurut Undang-Undang No. 13 Tahun 2003 bahwa setiap perusahaan diwajibkan untuk memperhatikan keselamatan dan kesehatan karyawannya. Tujuan kesehatan kerja adalah :

1. Meningkatkan dan memelihara derajat kesehatan tenaga kerja yang setinggitingginya baik fisik, mental maupun sosial.

2. Mencegah dan melindungi tenaga kerja dari gangguan kesehatan yang disebabkan oleh kondisi lingkungan kerja.

3. Menyesuaikan tenaga kerja dengan pekerjaan atau pekerjaan dengan tenaga kerja.

4. Meningkatkan produktivitas pekerja.

Sedangkan Keselamatan kerja bertujuan untuk membuat kondisi kerja yang aman dengan dilengkapi alat-alat pengaman, penerangan yang baik, menjaga lantai dan tangga bebas dari air, minyak, nyamuk dan memelihara fasilitas air yang baik.

\section{LANDASAN TEORI}

\section{Manajemen Sumber Daya Manusia}

Organisasi adalah suatu sistem, terdiri dari orang - orang yang saling mempunyai ketergantungan, bekerja sama dengan arah dan tujuan yang sama, baik untuk mencapai 
tujuan yang sama, baik untuk mencapai tujuan pribadi. Organisasi akan dapat menjalankan fungsinya jika didalamnya ada pengelolaan (manajemen) yang baik, sehingga manajemen dan organisasi merupakan dua pengertian yang tidak dapat dipisahkan.

Manajemen Sumber Daya Manusia (MSDM) bukanlah suatu yang baru di lingkungan organisasi yang terdiri dari orang - orang yang secara sengaja melakukan kerjasama untuk mencapai tujuan, secara terus menerus melakukan upaya untuk mendapatkan yang terbaik sebagai hasil kerjanya. Upaya-upaya manusia tersebut bukan sesuatu yang bersifat statis, tetapi terus berkembang dan berubah seirama dengan dinamika perubahan kehidupan manusia.

\section{Keselamatan Kerja}

Menurut Ernawati (2009:201), keselamatan kerja adalah keselamatan yang berhubungan dengan peralatan, tempat kerja dan lingkungan, serta cara-cara melakukan pekerjaan. Keselamatan kerja menjadi aspek yang sangat penting, mengingat resiko bahayanya dalam penerapan teknologi. Keselamatan kerja merupakan tugas semua orang yang bekerja, setiap tenaga kerja dan juga masyarakat pada umumnya. Keselamatan kerja adalah membuat kondisi kerja yang aman dengan dilengkapi alat-alat pengaman, penerangan yang baik, menjaga lantai dan tangga bebas dari air, minyak, nyamuk dan memelihara fasilitas air yang baik. Menurut Malthis dan Jackson (2002:71), keselamatan kerja menunjuk pada perlindungan kesejahteraan fisik dengan dengan tujuan mencegah terjadinya kecelakaan atau cedera terkait dengan pekerjaan.

\section{Kesehatan Kerja}

Kesehatan kerja adalah bagian dari ilmu kesehatan yang bertujuan agar tenaga kerja memperoleh keadaan kesehatan yang sempurna baik fisik, mental maupun sosial (Lalu Husni, 2005:137). Selain itu, kesehatan kerja menunjuk pada kondisi fisik, mental dan stabilitas emosi secara umum dengan tujuan memelihara kesejahteraan individu secara menyeluruh. Sedangkan menurut Prabu Mangkunegara (2001:158) pengertian kesehatan kerja adalah kondisi bebas dari gangguan fisik, mental, emosi atau rasa sakit yang disebabkan lingkungan kerja.

\section{Tujuan Program Keselamatan dan Kesehatan Kerja}

Program keselamatan dan kesehatan kerja bertujuan untuk memberikan iklim yang kondusif bagi para pekerja untuk berprestasi, setiap kejadian baik kecelakaan dan penyakit kerja yang ringan maupun fatal harus dipertanggungjawabkan oleh pihak-pihak yang bersangkutan. Sedangkan menurut Rizky Argama (2006:230), tujuan dari dibuatnya program keselamatan dan kesehatan kerja adalah untuk mengurangi biaya perusahaan apabila timbul kecelakaan kerja dan penyakit akibat hubungan kerja.

Menurut Ernawati (2009:98), tujuan program Keselamatan dan Kesehatan Kerja (K3) adalah:

1. Melindungi para pekerja dari kemungkinan-kemungkinan buruk yang mungkin terjadi akibat kecerobohan pekerja.

2. Memelihara kesehatan para pekerja untuk memperoleh hasil pekerjaan yang optimal.

3. Mengurangi angka sakit atau angka kematian diantara pekerja. 
4. Mencegah timbulnya penyakit menular dan penyakit-penyakit lain yang diakibatkan oleh sesama pekerja.

5. Membina dan meningkatkan kesehatan fisik maupun mental.

6. Menjamin keselamatan setiap orang yang berada di tempat kerja.

7. Sumber produksi dipelihara dan dipergunakan secara aman dan efisien.

\section{METODOLOGI PENELITIAN}

Lokasi penelitian di UD. Berkat Jalan Desa Botolakha Kecamatan Tuhemberua Kabupaten Nias Utara. Jenis penelitian ini menggunakan jenis deskriptif kualitatif. Penelitian deskriptif, merupakan penelitian yang bertujuan untuk mengungkapkan fakta yang sudah ada dan mendeskripsikan sesuai fenomena. menurut Lexy. J. Moleong (2007:102) Pengertian dari penelitian deskriptif adalah data yang dikumpulkan berupa kata-kata, gambar dan bukan angka-angka. Hal ini disebabkan oleh adanya penerapan metode kualitatif. Selain itu semua yang dikumpulkan berkemungkinan menjadi kunci terhadap apa yang sudah diteliti. Penelitian deskriptif bertujuan menggambarkan secara sistematik dan akurat fakta dan karakteristik mengenai populasi atau mengenai bidang tertentu. Penelitian ini berusaha menggambarkan situasi atau kejadian. Data yang dikumpulkan semata-mata bersifat deskriptif sehingga tidak bermaksud mencari penjelasan, menguji hipotesis, membuat prediksi, maupun mempelajari implikasi. (Yin, 1996:93). Di dalam melakukan penelitian, populasi sangat penting sekali karena, merupakan sasaran yang akan diteliti. Menurut pendapat Sugiyono (2006 : 55) bahwa : "populasi adalah wilayah generalisasi yang terdiri atas objek atau subjek yang mempunyai kualitas dan karakteristik tertentu yang akan ditetapkan oleh peneliti untuk dipelajari dan kemudian ditarik kesimpulan". Oleh karena itu, yang menjadi populasi dalam penelitian ini adalah seluruh karyawan yang ada pada UD. Berkat sebanyak 35 orang.Sampel adalah sebagian atau mewakili populasi yang akan diteliti. sampel memiliki peranan dalam penelitian ini dalam rangka memperoleh data yang di teliti. Menurut suarsimi (1993: 120), mengatakan bahwa : "apabila subjek kurang dari 100, lebih baik diambil semua, sehingga penelitian merupakan penelitian populasi, selanjutnya jika subjek lebih besar dapat di ambil antara 10\%-15\% atau 10\%-25\% atau lebih". Oleh karena populasi dalam penelitian ini tidak terlalu banyak dan kurang dari 100 maka penulis mengambil jumlah semua populasi sebagai sampel penelitian. Jadi sampel dalam penelitian ini adalah manager dan juga seluruh karyawan UD. Berkat yang seluruhnya berjumlah 35 orang.

\section{HASIL PENELITIAN}

Sesuai dengan penjelasan pada bab sebelumnya, bahwa yang menjadi sampel sekaligus sebagai responden pada penelitian ini adalah seluruh seluruh karyawan yang ada pada UD. Berkat sebanyak 35 orang. Maka oleh karena itu, penulis dapat menguraikan karakteristik responden berdasarkan jenis kelamin, pendidikan terakhir serta golongan dan pangkat, sebagai berikut :

\section{Jenis Kelamin}


Gambaran responden penelitian, akan penulis uraikan berdasarkan jenis kelamin, sebagai berikut :

Tabel 4.1 : Karakteristik Responden berdasarkan Jenis Kelamin

\begin{tabular}{|c|c|c|}
\hline Jenis Kelamin & Frekuensi & Persentase (\%) \\
\hline Laki-Laki & 21 & 60 \\
\hline Perempuan & 14 & 40 \\
\hline Jumlah & 35 & 100 \\
\hline
\end{tabular}

Sumber: UD. Berkat

\section{Tingkat Pendidikan}

Selanjutnya, penulis akan menyajikan karakteristik responden berdasarkan pendidikan terakhir, sebagai berikut :

Tabel 4.2 : Karakteristik Responden berdasarkan Pendidikan Terakhir

\begin{tabular}{|c|c|c|}
\hline $\begin{array}{l}\text { Pendidikan } \\
\text { Formal }\end{array}$ & Frekuensi & Persentase (\%) \\
\hline SD & - & - \\
\hline SMP & 2 & 5.71 \\
\hline SMA & 20 & 57.14 \\
\hline D3 & 3 & 8.57 \\
\hline S1 & 10 & 28.57 \\
\hline Jumlah & 35 & 100 \\
\hline
\end{tabular}

Sumber: UD. Berkat

\section{Umur}

Karakteristik responden berdasarkan umur sebagai berikut :

Tabel 4.3 : Karakteristik Responden Berdasarkan Umur

\begin{tabular}{|l|l|l|}
\hline Umur & Frekuensi & Persentase (\%) \\
\hline
\end{tabular}




\begin{tabular}{|c|c|c|}
\hline $19-28$ tahun & 13 & 37.14 \\
\hline $29-38$ tahun & 17 & 48.57 \\
\hline $39-48$ tahun & 3 & 8.57 \\
\hline $49-56$ tahun & 2 & 5.71 \\
\hline Jumlah & 35 & 100 \\
\hline
\end{tabular}

Sumber : UD. Berkat

\section{Frekuensi Nilai Jaminan Kesehatan Kerja}

UD. Berkat telah memberikan jaminan terhadap keselamatan kerja kepada para karyawannya. Jaminan tersebut berupa jaminan kesehatan yaitu adanya biaya pengobatan yang diberikan perusahaan jika karyawan mengalami kecelakaan kerja serta menanggung seluruh resiko yang diakibatkan kecelakaan tersebut. Tetapi penerapan jaminan kesehatan dan keselamatan ini masih belum maksimal dilakukan perusahaan. Hal ini terbukti dengan tidak adanya Jamsostek (Jaminan Sosial Tenaga Kerja) yang diberikan perusahaan kepada seluruh karyawannya. Berdasarkan hasil wawancara yang diajukan penulis kepada seluruh responden maka dapat disusun frekuensi nilai kesehatan kerja di UD. Berkat sebagai berikut :

Tabel 4.4 : Deskripsi Variabel Kesehatan Kerja

\begin{tabular}{|c|c|c|c|}
\hline Interval & Kategori & Frekuensi & Persentase $(\%)$ \\
\hline $1,00-1,79$ & Sangat rendah & 0 & - \\
\hline $1,80-2,59$ & Rendah & 2 & 5.7 \\
\hline $2,60-3,39$ & Cukup tinggi & 8 & 22.9 \\
\hline $3,40-4,19$ & Tinggi & 18 & 51.4 \\
\hline $4,20-5,00$ & Sangat tinggi & 7 & 20 \\
\hline \multicolumn{2}{|c|}{ Jumlah } & 35 & 100 \\
\hline
\end{tabular}

Berdasarkan Tabel 4.4, dapat dilihat bahwa dari 35 responden yang memberi tanggapan terhadap item-item pernyataan variabel Kesehatan Kerja, tidak ditemukan responden $(0 \%)$ yang memiliki Kesehatan Kerja tergolong "sangat rendah" dan 2 orang $(5,7 \%)$ tergolong "rendah", 8 orang $(22,9 \%)$ tergolong "cukup tinggi", 18 orang $(51,4 \%)$ tergolong "tinggi" dan 7 orang $(20 \%)$ tergolong "sangat tinggi". Nilai rata-rata mean diperoleh sebesar 3,537. Nilai ini berada dalam rentang 3,40 - 4,19 yang berarti "tinggi". Ini menunjukkan bahwa tingkat Kesehatan Kerja karyawan UD. Berkat tergolong tinggi.

\section{Frekuensi nilai Keselamatan Kerja}


Berdasarkan hasil wawancara yang diajukan penulis kepada seluruh responden maka dapat susun frekuensi nilai Keselamatan Kerja di UD. Berkat sebagai berikut :

Tabel 4.5 : Deskripsi Variabel Keselamatan Kerja

\begin{tabular}{|c|c|c|c|}
\hline Interval & Kategori & Frekuensi & Persentase $(\%)$ \\
\hline $1,00-1,79$ & Sangat rendah & 0 & - \\
\hline $1,80-2,59$ & Rendah & 1 & 2.86 \\
\hline $2,60-3,39$ & Cukup tinggi & 5 & 14.29 \\
\hline $3,40-4,19$ & Tinggi & 24 & 68.57 \\
\hline $4,20-5,00$ & Sangat tinggi & 5 & 14.29 \\
\hline \multicolumn{2}{|c|}{ Jumlah } & 35 & 100 \\
\hline
\end{tabular}

Berdasarkan Tabel 4.5, dapat dilihat bahwa dari 35 responden yang memberi tanggapan terhadap item-item pernyataan variabel Keselamatan Kerja, tidak ditemukan responden $(0 \%)$ yang menilai "sangat rendah" 1 orang $(2,86 \%)$ menilai "rendah" pada Keselamatan Kerja, 5 orang (14,29\%) menilai "cukup tinggi”, 24 orang $(68,57 \%)$ menilai "tinggi” dan 5 orang $(14,29 \%)$ menilai "sangat tinggi". Nilai rata-rata diperoleh sebesar 3,715. Nilai ini berada dalam rentang 3,40 - 4,19 yang berarti "cukup tinggi". Ini menunjukkan bahwa Keselamatan Kerja pada UD. Berkat tergolong tinggi.

\section{Tingkat Kemangkiran Kerja Karyawan 2017}

Tabel 4.6 : Rekapitulasi Tingkat Kemangkiran Kerja Karyawan

UD. Berkat Tahun 2017

\begin{tabular}{|c|l|c|c|}
\hline No & Bulan & $\begin{array}{c}\text { Jumlah } \\
\text { Karyawan }\end{array}$ & $\begin{array}{c}\text { Rata-rata } \\
\text { tidak masuk } \\
\text { kerja }\end{array}$ \\
\hline 1 & Januari & 25 & 8 \\
\hline 2 & Februari & 28 & 9 \\
\hline 3 & Maret & 28 & 9 \\
\hline 4 & April & 28 & 6 \\
\hline 5 & Mei & 31 & 5 \\
\hline 6 & Juni & 30 & 8 \\
\hline 7 & Juli & 29 & 7 \\
\hline 8 & Agustus & 29 & 6 \\
\hline 9 & September & 30 & 6 \\
\hline 10 & Oktober & 30 & 8 \\
\hline
\end{tabular}




\begin{tabular}{|l|l|c|c|}
\hline 11 & November & 31 & 4 \\
\hline 12 & Desember & 29 & 7 \\
\hline \multicolumn{2}{|l|}{ Jumlah } & 83 \\
\hline \multicolumn{2}{|l|}{ Hari Efektif Bekerja } & 309 \\
\hline \multicolumn{2}{|l|}{ Persentase } & $27 \%$ \\
\hline
\end{tabular}

Sumber: UD. Berkat

\section{Tingkat Kemangkiran Kerja Karyawan Tahun2018}

Tabel 4.7 : Rekapitulasi Tingkat Kemangkiran Kerja Karyawan

UD. Berkat Tahun 2018

\begin{tabular}{|c|l|c|c|}
\hline No & Bulan & $\begin{array}{c}\text { Jumlah } \\
\text { Karyawan }\end{array}$ & $\begin{array}{c}\text { Rata-rata } \\
\text { tidak masuk } \\
\text { kerja }\end{array}$ \\
\hline 1 & Januari & 29 & 5 \\
\hline 2 & Februari & 29 & 4 \\
\hline 3 & Maret & 31 & 4 \\
\hline 4 & April & 31 & 2 \\
\hline 5 & Mei & 33 & 3 \\
\hline 6 & Juni & 33 & 1 \\
\hline 7 & Juli & 33 & 2 \\
\hline 8 & Agustus & 35 & 2 \\
\hline 9 & September & 35 & 4 \\
\hline 10 & Oktober & 35 & 2 \\
\hline 11 & November & 35 & 2 \\
\hline 12 & Desember & 35 & 1 \\
\hline \multicolumn{2}{|l|}{ Jumlah } \\
\hline \multicolumn{2}{|l|}{ Hari Efektif Bekerja } & $\mathbf{3 2}$ \\
\hline \multicolumn{2}{|l|}{ Persentase } \\
\hline
\end{tabular}

Sumber: UD. Berkat

Dari tabel diatas menunjukkan bahwa dengan penerapan program keselamatan dan kesehatan kerja di UD. Berkat memberikan manfaat bagi perusahaan dengan tingkat kemangkiran karyawan dalam melaksanakan tugas di perusahaan. Pada tahun 2017 tingkat kemangkiran karyawan sebesar 27\% tetapi pada tahun 2018 terjadi penurunan menjadi $10 \%$. Menurut seluruh karyawan yang menjadi responden, program keselamatan dan kesehatan kerja yang dilaksanakan perusahaan dapat memperkecil niat para karyawan tersebut untuk keluar dari UD. Berkat. Berikut disajikan tabel turnover karyawan pada tahun 2017 dan 2018 yaitu :

Tabel 4.9 : Turnover Karyawan UD. Berkat 
Tahun 2017 dan 2018

\begin{tabular}{|c|c|c|c|c|}
\hline Tahun & $\begin{array}{c}\text { Mutasi } \\
\text { Jabatan }\end{array}$ & $\begin{array}{c}\text { Mengundurkan } \\
\text { Diri }\end{array}$ & Masuk & $\begin{array}{c}\text { Jumlah } \\
\text { Karyawan }\end{array}$ \\
\hline 2017 & - & 11 & 2 & 30 \\
\hline 2018 & - & 5 & 6 & 35 \\
\hline
\end{tabular}

Retensi karyawan $=\frac{\text { Jumlah karyawan yang keluar }}{\text { Total Jumlah Karyawan }} \times 100 \%$

a. Turnover Karyawan $2011=\frac{11}{30} \times 100 \%$

$$
=37 \%
$$

b. Turnover Karyawan $2018=\frac{5}{35} \times 100 \%$

$$
=14 \%
$$

Berdasarkan tabel di atas dapat disimpulkan bahwa dengan penerapan program keselamatan dan kesehatan kerja memberikan manfaat bagi perusahaan dengan penurunan turnover karyawan dimana pada tahun 2011 sebesar $37 \%$ tetapi pada tahun 2018 mengalami penurunan sebesar $14 \%$.

\section{KESIMPULAN}

Berdasarkan uraian pembahasan diatas maka dapat ditarik beberapa kesimpulan yaitu: Penerapan kesehatan dan keselamatan kerja di UD. Berkat sudah sangat baik dan sesuai dengan yang diharapkan. Hal ini dapat terlihat dari persepsi karyawan yaitu:

a. Jaminan K3

UD. Berkat telah memberikan jaminan terhadap keselamatan dan kesehatan kerja kepada para karyawannya. Meskipun jaminan yang diberikan perusahaan tersebut masih belum sesuai dengan apa diharapkan dan dibutuhkan oleh para karyawannya. Hal ini disebabkan karena perusahaan masih belum mengikutsertakan seluruh karyawannya dalam program Jamsostek.

b. Pelatihan K3

UD. Berkat telah memberikan pelatihan keselamatan dan kesehatan kerja kepada para karyawannya, Pada dasarnya, pelatihan K3 yang diberikan oleh UD. Berkat dirasa telah cukup oleh sebagian besar karyawan yang menjadi responden untuk dapat membekali dirinya saat terjun ke tempat kerja.

c. Alat Pelindung Diri

UD. Berkat telah menyediakan kelengkapan alat pelindung diri. APD dari perusahaan tersebut dapat membuat sebagian besar karyawan yang menjadi responden merasa lebih aman dan nyaman dalam bekerja. 
d. Beban Kerja

Beban kerja yang ditetapkan oleh UD. Berkat sudah sesuai dengan peraturan yang berlaku.

e. Jam Kerja

Semua karyawan UD. Berkat tanpa terkecuali, bekerja enam hari dalam satu minggu. Namun kebijakan jam kerja tersebut masih sesuai dengan ketentuan undang-undang. Semua karyawan yang menjadi responden berpendapat bahwa jam kerja yang diberlakukan perusahaan telah sesuai dengan harapan dan kemampuan karyawan tersebut.

\section{UCAPAN TERIMA KASIH}

Pada kesempatan ini, peneliti mengucapkan terima kasih kepada pihak-pihak yang telah mendukung terselesainya penelitian ini antara lain :

1) Ketua STIE Pembangunan Nasional Gunungsitoli yang telah membantu dan membeikan izin kepada peneliti dalam memperoleh data di lokasi penelitian.

2) Keluarga buat istri Tiesda Zai, S.E dan ketiga anak saya (E. Valora Haga Zega, Brigita F. Zega dan E. Xiaoqing Zega) yang selalu turut mendoakan saya dalam menjalankan aktivitas setiap hari, yang setia memberikan cinta, kasih sayangnya dalam suka maupun duka.

3) Ketua Sekolah Tinggi Ilmu Ekonomi (STIE) Al-Washliyah Sibolga dan Tim Jurnal Ekonomi dan Ekonomi Syariah yang selalu memberikan kesempatan bagi peneliti untuk menulis jurnal.

4) Pihak UD. Berkat yang telah membantu penulis untuk memberikan informasi yang berkaitan dengan penelitian.

\section{DAFTAR PUSTAKA}

Arikunto, Suharsimi. 2007. Prosedur Penelitian, Suatu Pendekatan Praktik. Jakarta: PT. Rineka Cipta.

Argama Rizky, 2006. Manajemen Personalia, Terjemahan, Edisi Ketiga, Erlangga, Jakarta. Dessler, Gary, 1992. Manajemen Sumber Daya Manusia, Terjemahan, Edisi Kedua, Prehallindo, Jakarta.

Erickson, Roy. 2009, Manajemen Personalia, Terjemahan, Edisi Satu, Erlangga, Jakarta. Ernawati, 2009. Pengaruh Keselamatan dan Kesehatan Kerja Terhadap Kinerja Karyawan (Studi pada Karyawan Bagian Produksi PT. Surabaya Agung Industri Pulp \& Kertas). Skripsi Tidak di publikasikan oleh Universitas Brawijaya Malang.

Hadiguna R, Ampuh, 2009. Manajemen Sumber Daya Manusia (Kebijaksanaan Kerja Karyawan), BPFE, Yogyakarta.

J. Moleong, Lexy. 2007. Metodologi Penelitian Kualitatif, Edisi Revisi Bandung: Remaja Rosdakarya.

Kuncoro, M. 2001. Pokok-pokok Materi Metodologi Penelitian dan Aplikasinya. Jakarta: Ghalia Indonesia.

Mangkuprawira, Syafri dan Hubeis A.V, 2007. Manajemen Keselamatan dan Kesehatan Kerja, PT Pustaka Binaman Pressindo, Jakarta.

Mathis, Robert L dan Jackson. John H, 2002. Manajemen Sumber Daya Manusia, Penerbit 
Salemba Empat, Jakarta.

Modjo, Robiana, 2007, Pendekatan Manusia dan Organisasi Terhadap Pembinaan Kepegawaian. Cetakan Ke - 1, Gunung Agung. Jakarta.

Nazir. 1998. Metodologi Penelitian. Jakarta: Raja Grafindo Persada.

Peraturan Pemerintah Nomor 17 Tahun 1993 tentang Penyelenggaraan Program Jaminan Sosial Tenaga Kerja

Randall. S. Schuler dan Sussan E Jackson, 1999. Manajemen Sumber Daya Manusia, Terjemahan, Edisi keenam, Cetakan 1, Erlangga, Jakarta.

Tulus, 1992. Manajemen Tenaga Kerja Indonesia. Bumi Aksara, Yogyakarta.

Sabir, 2009, Ketenagakerjaan, Ghalia Indonesia, Jakarta.

Soeprihanto, 1996. Manajemen Produksi dan Operasi, Edisi 1 BPFE, Yogyakarta.

Soegiyono, 1998. Metode Penelitian Bisnis, Cetakan Kedua, CV.Alfabeta, Bandung.

Suma'mur. 1993. Keselamatan Kerja dan Pencegahan Kecelakaan. Penerbit Gunung Agung, Jakarta.

Undang-undang Nomor 13 Tahun 2003 tentang Kesehatan dan Keselamatan Kerja (K3)

Undang-undang Menteri Kesehatan RI No. 9 Tahun 1960 Tentang Standar Kesehatan

Yin, 1996. Cara Mudah Menulis Proposal Dan Laporan Penelitian Lapangan. Malang, UM Press 